\title{
Analysis of ploidy in hypopharyngeal cancer by laser scanning cytometry on fine needle aspirate biopsies
}

\author{
Andreas O.H. Gerstner ${ }^{\mathrm{a}, *}$, Julia Machlitt ${ }^{\mathrm{a}}$, Hans-Jürgen Welkoborsky ${ }^{\mathrm{b}}$, Friedrich Bootz ${ }^{\mathrm{a}}$ and \\ Attila Tárnok ${ }^{\mathrm{c}}$

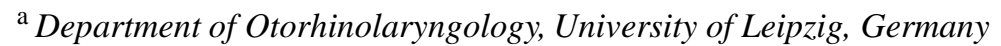 \\ ${ }^{\mathrm{b}}$ Department of Otorhinolaryngology, Nordstadt Clinic, Academic Hospital, Hannover, Germany \\ ${ }^{\mathrm{c}}$ Department of Pediatric Cardiology, Cardiac Center, University of Leipzig, Germany
}

Received 15 February 2002

Accepted 10 July 2002

\begin{abstract}
Aim: To test laser scanning cytometry (LSC) for the analysis of ploidy in squamous cell carcinoma of the hypopharynx $(\mathrm{SCCH})$ and to develop a routine application for minimal samples such as fine needle aspirate biopsies (FNABs). Methods: From 11 individuals 30 FNABs of primary tumors $(n=11)$ and lymphatic metastases of SCCH $(n=11)$ and non-metastatic lymph nodes $(n=8)$ are analyzed by LSC. This microscope based instrument scans the cells after immobilization on a glass slide and after double staining of cytokeratin and DNA. The location of each cell is stored with the fluorescence data. Therefore the morphology of every cell can be documented by re-staining with H\&E and re-localization on the slide. Additionally, aliquots are Feulgen-stained for image cytometry in 8 specimens. Results: The diploid reference peak is identified taking leukocytes as internal standard. The DNA-index of the carcinoma cells ranges from 0.4 to 3.8. Comparison with image cytometry shows good correlation $(r=0.89)$. Conclusion: LSC provides a reliable and objective way to determine the ploidy of SCCH pre-operatively.

Colour figures can be viewed on http://www.esacp.org/acp/2003/25-2/gerstner.htm
\end{abstract}

Keywords: Ploidy, carcinoma of the hypopharynx, comparative study, LSC, slide-based cytometry, image cytometry, Feulgenstaining, eosinophils

\section{Introduction}

In clinical oncology, a growing number of relevant data is gained by cytological analyses. Up to now the ploidy of solid carcinomas is determined by established cytometric methods such as image analysis and flow cytometry. Both methods are well described and various standardized protocols have been published [3, $21,39]$. For image analysis, exact protocols with detailed recommendations concerning all aspects of the methodology (from sample preparation and staining to analysis and interpretation) exist $[14,16,17]$. However, there are major disadvantages to both methods

\footnotetext{
*Corresponding author: Dpt. of Otorhinolaryngology, University of Leipzig, Liebigstr. 18a, D-04103 Leipzig, Germany. Tel.: +49 341972 1700; Fax: +49 341972 1709; E-mail: gersta@medizin. uni-leipzig.de.
}

that in part might have led to the controversial assessment of their clinical use. For image analysis, in general about 300 cells are analyzed and in most protocols only parameters concerning the cellular DNA (e.g., ploidy) are determined [31]; cells to be analyzed are selected by the observer which makes analysis time consuming and might lead to inter-observer variations. For flow cytometry, in the vast majority of cases cells are not available for a second (morphological) analysis once they have passed the detector chamber. The only exception is cell sorting where cells with selected characteristics can be collected. This is a timeconsuming procedure not suitable for routine purposes and data cannot be re-addressed to individual cells. Furthermore, physical stress on the cells during passage through the nozzles might yield to substantial artifacts. Moreover, the sample must have a rather high cell count in order to obtain a satisfying analysis. 
In the present study we were looking for an alternative method to determine the ploidy of epithelial cells in squamous cell carcinoma of the hypopharynx (SCCH) using the laser scanning cytometer (LSC). The LSC combines the advantages of both, image cytometry and flow cytometry, but avoids their disadvantages. This instrument is built around a conventional epifluorescence microscope [24]. The cells of the specimen are immobilized on a glass microscope slide and are treated by appropriate fluorescence staining assays. For analysis the slide is scanned stepwise by one or two lasers sequentially with a rate of up to 5,000 cells per minute. Until now, up to six fluorescence parameters and one light scattering parameter are simultaneously determined [11]; additionally, the $\mathrm{x}$ - and $\mathrm{y}$-coordinate of every single cell is stored with the data. After analysis, the slide can be removed and cells can be restained by any conventional cytopathological staining, e.g., hematoxylin-eosin [10]. After re-staining every cell can be re-localized on the slide and its morphology can be documented with the built-in CCD-camera. Specimens can be archived for reviewing.

In the clinical context most applications of LSC have been developed for analysis of leukocytes (for a detailed review on LSC see [38]). For the analysis of the ploidy in clinical samples several studies compared LSC with image cytometry and flow cytometry $[5,28$, 32,33]; however, in these studies tumor cells were obtained by dissociation of tissue blocks after resection of the tumor or by touch imprints on the fresh cut surface. In order to improve the therapeutic management of patients we were actually looking for an assay that could be applied pre-operatively prior to the resection of the tumor; analysis therefore had to be optimized using hypocellular specimens such as fine-needle aspiration biopsies (FNABs). So far an assay has been described for peritoneal and bladder washes and other effusions [42]. For our study we have developed an assay that allows to determine the ploidy of SCCH by LSC using FNABs.

\section{Material and methods}

\subsection{Specimens}

FNABs are taken in the out-patient department or immediately after resection of the primary tumor, the lymph nodes, and suspected metastases with a $27 \mathrm{G}$ needle and a $20 \mathrm{ml}$ syringe. The material obtained is suspended in a $1.5 \mathrm{ml}$ Eppendorf tube (Eppendorf,
Hamburg, Germany) pre-filled with $100 \mu \mathrm{l}$ phosphate buffered saline (PBS; Gibco BRL, Paisley, Scotland, UK) $\mathrm{pH} 7.40$ with $1 \%$ bovine serum albumin (BSA; Sigma, St. Louis, MO, USA) and stored at $4{ }^{\circ} \mathrm{C}$ for up to $24 \mathrm{~h}$ until further preparation. Initially, any patient presenting with a cervical mass was biopsied. Out of more than 200 patients effectively 11 patients with 30 specimens were included into this study. Inclusion criterion was a previously unknown, newly diagnosed hypopharyngeal cancer. Exclusion criteria were omission of surgery due to disease stage or irradiation of the tumor prior to surgery.

\subsection{Preparation}

For double-staining of cytokeratin and DNA $1 \mathrm{ml}$ FACSLysis (BD Biosciences, San Jose, CA, USA) is added to each tube. Tubes are incubated for $15 \mathrm{~min}$ at room temperature. After spinning at $250 \times g$ for 5 min the supernatant is decanted and the pellet is resuspended in $50 \mu \mathrm{l}$ PBS with $0.5 \%$ BSA. 1-2 $\mu \mathrm{l}$ of the suspension are checked in the microscope for the density of the cells. Depending on the density 10-20 $\mu \mathrm{l}$ are transferred to two quadratic areas each measuring $1.2 \times 1.2 \mathrm{~cm}$ on a conventional glass microscope slide. As a general rule cells dispersed on the slide should lie mainly as distinct cells and the distance to every neighboring cell should equal the diameter of a cell. For each specimen at least one slide with two areas is prepared (for specific staining and negative control, resp.). Slides are air-dried for $1 \mathrm{~h}$ and stored in $70 \%$ ethanol at room temperature.

\subsection{Staining}

Slides are removed from the ethanol and placed in a container filled with PBS for $5 \mathrm{~min}$. Slides are removed from the container and the areas where the cells were transferred onto are encircled with a fat pen (DAKOPen; Dako, Carpinteria, CA, USA). $200 \mu \mathrm{l}$ of PBS with $1 \%$ BSA are pipetted onto each area and slides are incubated for $15 \mathrm{~min}$ at room temperature. After decanting by inversion, areas are incubated either with $5 \mu$ l of FITC-conjugated anti-cytokeratinantibody recognizing several basic and acidic cytokeratins (Clone MNF116, Code F0859) or with unspecific control-antibody (Code X0927; both purchased from Dako) in $100 \mu \mathrm{l}$ PBS with $0.5 \%$ BSA for $30 \mathrm{~min}$ at room temperature in the dark in a humidified chamber. After decanting by inversion areas are washed with $0.5 \mathrm{ml}$ PBS twice and then are incubated with 
$100 \mu \mathrm{l}$ PBS with $0.5 \%$ BSA containing $5 \mu \mathrm{l}$ antiFITC-antibody conjugated to Alexa-Green ${ }^{\circledR}$ diluted $1: 100$ (A-11090; Molecular Probes Europe BV, Leiden, The Netherlands) and $50 \mu \mathrm{g} \mathrm{PI} / \mathrm{ml}$ (Sigma, St. Louis, MO, USA) and $0.1 \mathrm{mg}$ RNase (Sigma) for $30 \mathrm{~min}$ in the dark in a humidified chamber. After decanting by inversion areas are washed with $0.5 \mathrm{ml}$ PBS twice and then are covered with $40 \mu \mathrm{l}$ of glycerol in PBS 75\%/25\% with $25 \mu \mathrm{g} \mathrm{PI} / \mathrm{ml}$ each.

\subsection{Data acquisition}

The design of the LSC is described in detail elsewhere [25]. For data acquisition, the slide is placed on the motorized stage of the LSC. The focal plane is adjusted with the $20 \times$ objective. In the proprietary software (WinCyte ${ }^{\circledR}$ ) the scan area is fitted to the actual area of the slide where the cells are placed. This step is performed with minimal light exposure of the cells. Then the parameter and photomultiplier (PMT) settings are adjusted: the contouring signal is set on the fluorescence-3-channel (FL3 = red fluorescence, PI), the minimal area is $20 \mu \mathrm{m}^{2}$, the threshold level is 1200. The threshold setting is checked at the beginning of the analysis to ensure that neither cells are lost for analysis nor fused to doublets. Data are gained for FL1 (green, FITC) and FL3 (red, PI) and for forward scatter (FSC) after excitation with the argon laser (power set to $5 \mathrm{~mW}$ ). For FL1 and FL3, PMT-voltage, -offset, and -gain are set to $30 \%, 2075$, and 255, respectively. For FSC no voltage has to be set, offset and gain are adjusted to 2020 and 20, respectively. Data are stored in list mode files (FCS 3.0 version).

\subsection{Cytomorphological staining}

After analysis in the LSC the slide is removed from the stage and the coverslip is detached by placing the slide vertically in a container filled with PBS for 15 to 60 min to allow the cover to slip off. Then a conventional hematoxylin-eosin staining is performed. Slides are covered again using Eukitt (Kindler GmbH\&Co, Freiburg, Germany) and are stored as normal cytological samples.

\subsection{Data analysis and interpretation}

For analysis, a dotplot showing PI vs. FITC is created. In this dotplot gates are set in the negative control with a cut-off at 5\% (see Fig. 1a) which are applied to separate the FITC-positive and FITC-negative fractions in the specifically stained sample (see Figs 1b-3). For the specifically stained sample an overlay histogram for PI showing the data of all cells and that of the cytokeratin positive fraction only is created. For interpretation, the slide is stained with $\mathrm{H} \& \mathrm{E}$ and placed back onto the LSC stage. The morphology of the cells is confirmed in each separate sub-population after relocalization in the microscope. Images of the cells are taken with the built-in CCD-camera. This feature allows to determine the diploid reference population and to discriminate it from artifacts. Therefore, the diploid peak can be marked in the PI-histogram and the DNAindex (DI) of the cytokeratin-positive sub-populations can be calculated (see Figs 1b-3). The coefficient of variation $(\mathrm{CV})$ of the different peaks within the DNAhistogram is calculated. In addition, the percentage of cytokeratin-positive cells with a DNA-content exceeding $5 \mathrm{c}$ (5c-exceeding rate $=5 \mathrm{cER})$ among all cytokeratin-positive cells is calculated.

\subsection{Feulgen staining [8]}

In order to validate the DI determined by LSC, samples were treated for analysis by standard image cytometry. By taking an extra aliquot of the sample cells were prepared with Feulgen-staining as described earlier [2] with minor modifications. Specimens were removed from the ethanol, rehydrated, and post-fixed in $4 \%$ paraformaldehyde for $30 \mathrm{~min} .5 \mathrm{~N} \mathrm{HCl}$ was applied at $25^{\circ} \mathrm{C}$ for $60 \mathrm{~min}$, followed by staining in Schiff's reagent (Merck, Darmstadt, Germany) at $25^{\circ} \mathrm{C}$ for $60 \mathrm{~min}$. Slides were then rinsed in $\mathrm{SO}_{2}$-water and dehydrated by increasing ethanol concentrations. The slides were then covered in Eukitt (Kindler, Freiburg, Germany) and stored in the dark. Quantitative DNA measurements were then performed using a computerized TV based image analysis system (Autocyte, Zeiss, Oberkochen, Germany). The system consists of a microscope (Axioscope, Zeiss) with an attached 3CCDvideocamera (Sony). The performance of the system meets the standards of the ESACP task force on standardization in diagnostic image cytometry [14]. At least 300 tumor cells were measured at random after detection on the TV screen. To determine the individual normal $2 \mathrm{c}$ peak at least 25 lymphocytes were mea- 


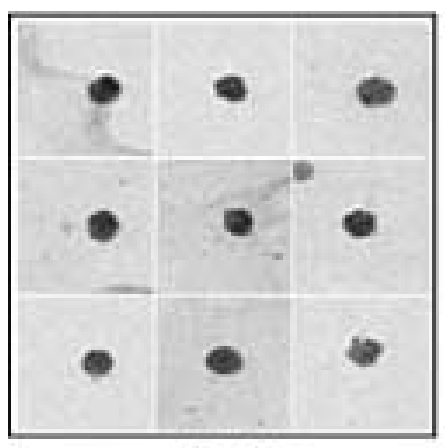

Gate E

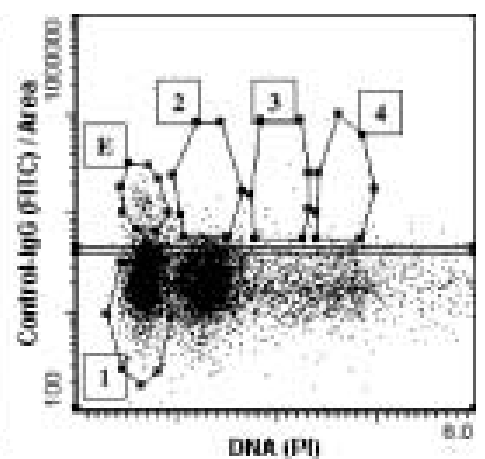

(a)
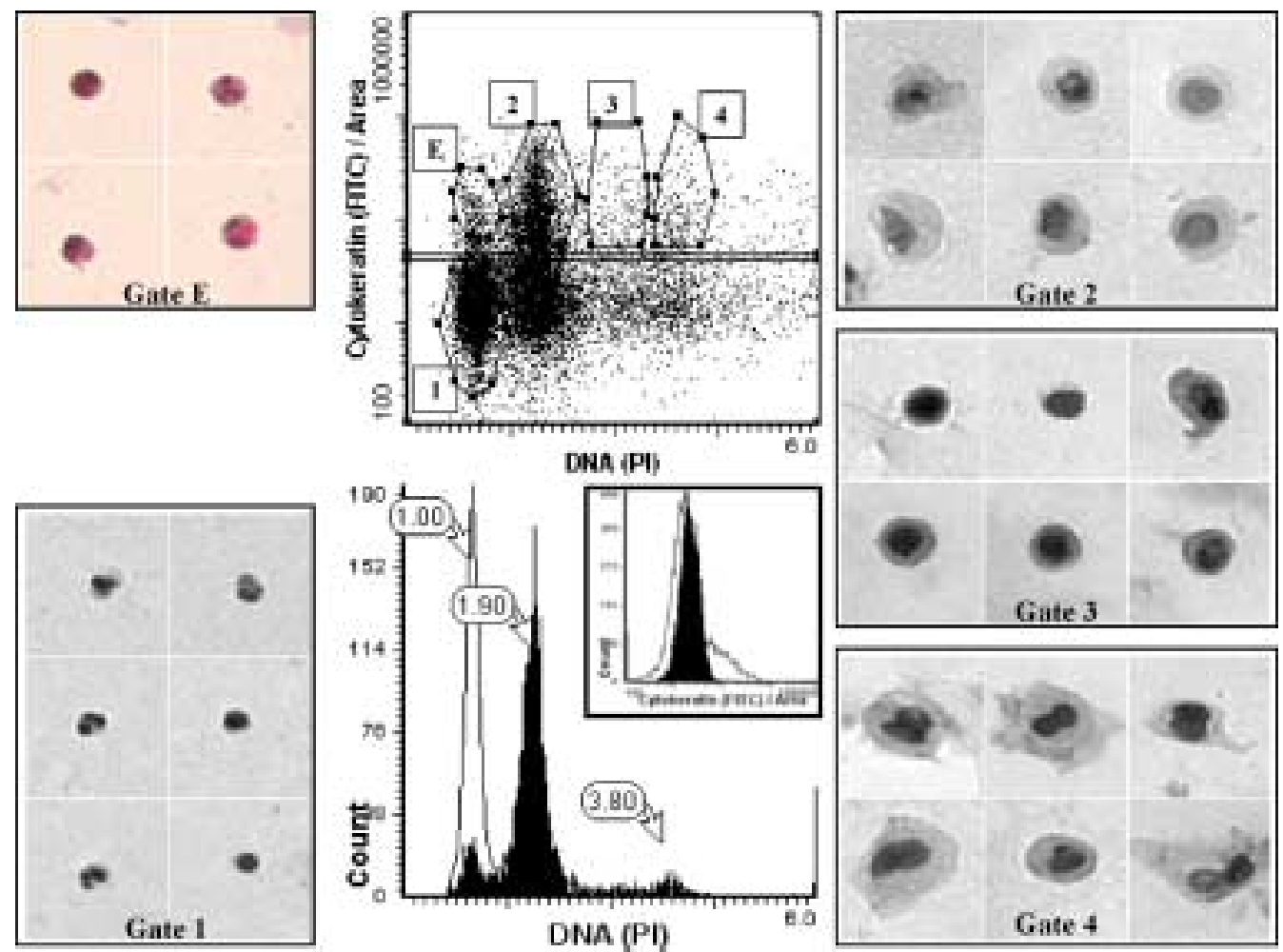

(b)

Fig. 1. FNAB from a hypopharyngeal carcinoma (histologically $\mathrm{pT}_{2} \mathrm{pN}_{2 \mathrm{~b}} \mathrm{M}_{0} \mathrm{G}_{2}$, patient \#58) processed as described with (a) negative control antibody or (b) a specific antibody stained. The dot plot represents the DNA content (x-axis, linear) vs. the cytokeratin expression per area (y-axis, logarithmic). The horizontal line shows the 5\%-cut off level set in the negative control. Gates 1-4 and gate E are set on major sub-populations of the specifically stained sample. The histogram in the lower center of Fig. 1(b) shows DNA content of the specific staining (black line: cytokeratin negative fraction; black area: cytokeratin positive fraction). The histogram inset shows green fluorescence of the negative control (black area) vs. specific staining (black line). Images in the frames are taken with the built in CCD-camera and represent H\&E stained cells re-localized from the respective gates set in the dot plot (gate 1: leukocytes; gates 2-4: epithelial cells; gate E: eosinophils). Their respective DI is indicated in the DNA-histogram. For the negative control only cells in gate E are shown. Total cell count (specifically stained sample): 17069 . This figure can be viewed on http://www.esacp.org/acp/2003/25-2/gerstner.htm 


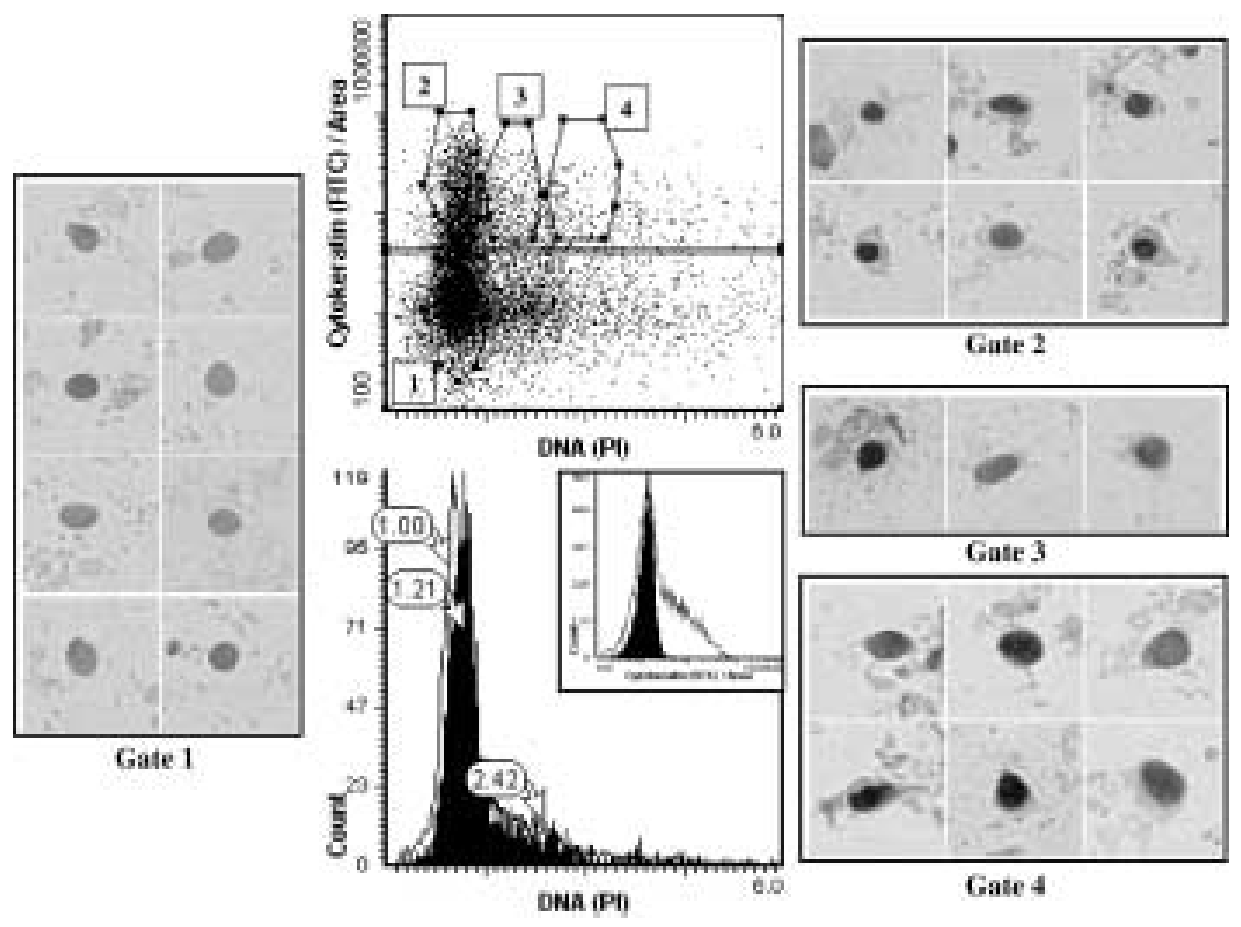

Fig. 2. Same patient as in Fig. 1 but FNAB was taken from a lymphatic metastasis in the left neck (Meta \#1 in Table 1). Note the different values determined for the DI as compared to the primary tumor. (For set-up of the figure see Fig. 1.) Total cell count: 10541.

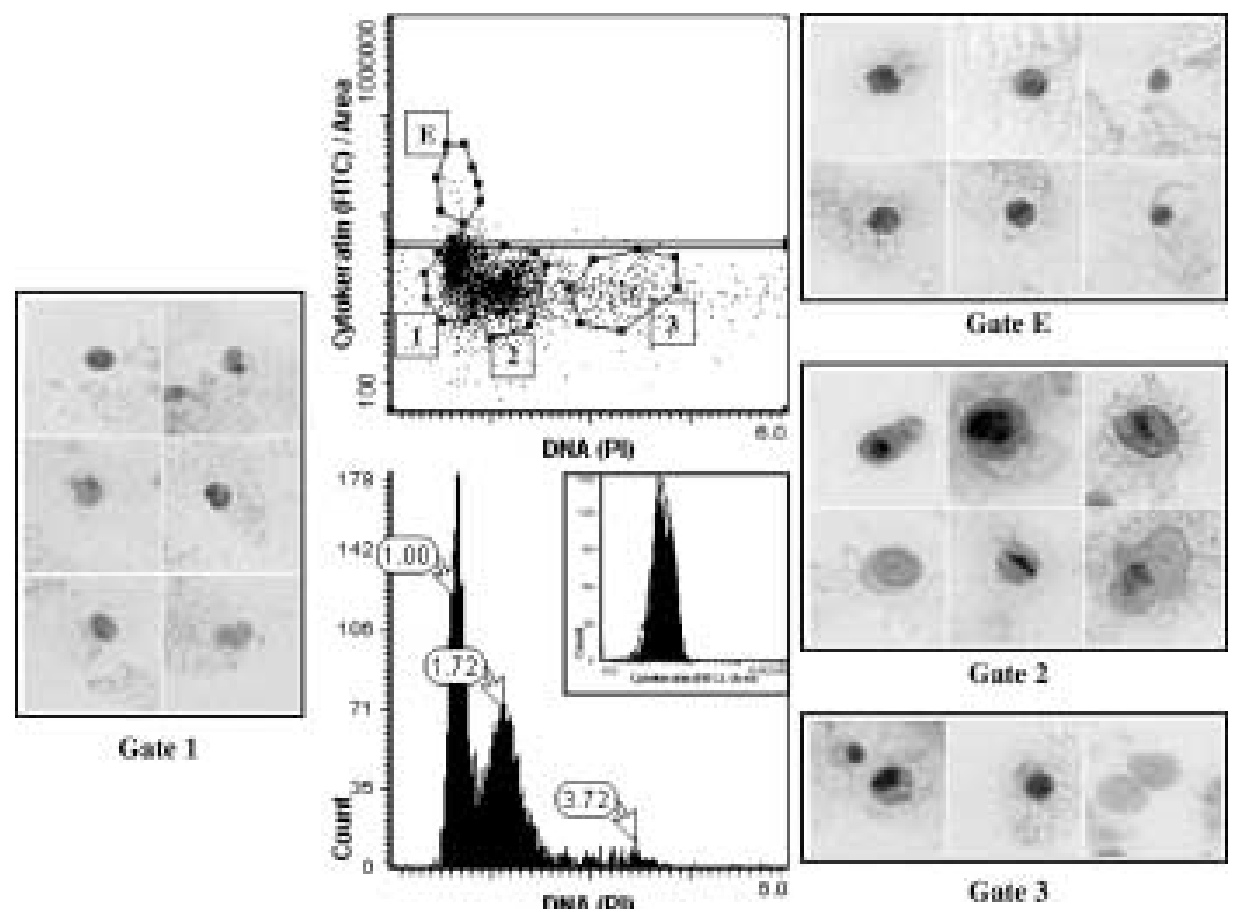

Fig. 3. Same patient as in Figs 1 \& 2 but FNAB was taken from a lymphatic metastasis in the right neck (Meta \#2 in Table 1). Note that cells do not show specific green fluorescence for cytokeratin but are clearly epithelial (gates $2 \& 3$ ) or are eosinophils (gate E). Note the different values determined for the DI as compared to the primary tumor and the other metastasis. (For set-up of the figure see Fig. 1.) Total cell count: 3937. 
sured as reference cells in the same sample. Measurement and data analysis was performed using the AutoCyte QUIC-DNA image analysis software (AutoCyte, Burlington, NC, USA).

\section{Results}

\subsection{Specimen preparation}

Included in this study were eleven patients with newly diagnosed hypopharyngeal carcinoma. All resected tissue was sent to routine histopathological analysis which in all cases confirmed the diagnosis of primary or metastasizing squamous cell carcinoma and disease free lymph node, respectively. In general, FNABs typically yielded between 3000-20000 cells (in primary tumors) and up to 100000 cells (lymph nodes and metastases). Slides could be stored in $70 \%$ ethanol for up to six months before further preparation without any detectable effect on the cytokeratin staining.

\subsection{Cytokeratin staining}

Cytokeratin staining was restricted to the cytoplasm in all cases. In all samples there was a sub-population of varying proportion that showed the same DNA content as the tumor cells but was cytokeratin negative. By re-localization this sub-population turned out to consist of events that in the vast majority were nuclei without cytoplasm. This correlated well with the observation of positively stained cytoskeletons without nuclei that could be found by direct visual examination of the slides in the epifluorescence microscope of the LSC. In several cases there was remarkably different cytokeratin staining intensity between the primary tumor and its metastasis/metastases which occurred to be partially negative in some cases (see Fig. 3). There were no cytokeratin positive cells in biopsies from histologically disease free lymph nodes.

\subsection{Morphological analysis and determination of ploidy}

Morphological analysis of the cells in the different sub-populations was easily performed after H\&E staining by re-localizing the cells of interest. Removing the coverslip produced some cell loss but this never exceeded 5\%. This cell loss was not specific to a certain sub-population.
For primary tumors and metastases, the determination of the ploidy was performed in the specifically stained sample. The DNA-histogram of the cytokeratin-positive fraction was analyzed and the DI of its peak or peaks was determined (see Figs 1b-3). The DI of the tumor cells in primary tumors and metastases ranged from 0.4 to 3.8 (see Table 1). For lymph nodes and benign tumors, the DNA histogram showed only one peak. The case of a histologically confirmed pleomorphic adenoma of the parotid gland was taken as a control; the DI of its epithelial cells was 1.0 (see Table 1). The CV of the DNA-peak of the diploid reference population ranged from 4.4 to $13.6 \%$, for the tumor cells the CV ranged from 4.5 to $18.0 \%$. In some cases there was a remarkable difference between the ploidy of the primary tumor and its metastases (see Figs $1 b-3$ and Table 1).

\subsection{Correlation with Feulgen-staining}

Among the many parameters determined by image analysis the percentage of aneuploid cells with a DNA content exceeding 5c (5cER) was calculated according to the same mathematical model as applied in LSC. We therefore compared the DNA-histograms obtained by both methods graphically (Fig. 4) and calculated Pearsons coefficient of correlation for the $5 \mathrm{cER}$ showing a high correlation of both methods (Fig. 5).

\section{5. "False cytokeratin-positive" cells}

In specimens of six of the patients a diploid population with bright green fluorescence appeared (see Figs 1b \& 3). These cells could be identified by relocalization as eosinophilic granulocytes and were also detected in the corresponding negative controls (see Fig. 1a, Gate E). All specimens were analyzed applying gate $\mathrm{E}$ (Figs $1 \mathrm{a}$ and $\mathrm{b}$ ); however, only in nine specimens eosinophils were detected. This finding was confirmed by direct microscopic visualization of the H\&E stained specimens.

\section{Discussion}

Colour figures can be viewed on http://www.esacp. org/acp/2003/25-2/gerstner.htm

Although it is still an issue under discussion there is growing evidence that aneuploidy is rather a cause than a consequence of cancer $[27,35]$. Aneuploidy has been identified to be prognostically relevant in several tumor 
Table 1

Analysis of the DNA-index (DI) and 5c-exceeding rate (5cER) in 11 cases of newly diagnosed primary tumors and metastases of $\mathrm{SCCH}$

\begin{tabular}{|c|c|c|c|c|c|c|}
\hline \multicolumn{2}{|c|}{$\begin{array}{l}\text { Pat. \# (pTpNcM) } \\
\text { age(years), } m / f\end{array}$} & $\begin{array}{r}\text { Peak \#1 } \\
\text { DI / CV-\% }\end{array}$ & $\begin{array}{r}\text { Peak \#2 } \\
\text { DI / CV-\% }\end{array}$ & $\begin{array}{r}\text { Peak \#3 } \\
\text { DI / CV-\% }\end{array}$ & $\begin{array}{r}\text { Peak \#4 } \\
\text { DI / CV-\% }\end{array}$ & $5 \mathrm{cER}$ \\
\hline \multirow{2}{*}{\multicolumn{2}{|c|}{$\# 24\left(\mathrm{~T}_{2} \mathrm{~N}_{2 \mathrm{~b}} \mathrm{M}_{0}\right), 47, \mathrm{~m}$}} & & & & & \\
\hline & Eost & $1.0 / 44 \%$ & $1.2 /$ n.a. & $1.9 / 7.7 \%$ & $2.7 /$ n.a. & $31 \%$ \\
\hline $\begin{array}{l}\text { Meta. } \\
\text { LN }\end{array}$ & Eos+ & \multicolumn{4}{|l|}{$10.4 .4 \%:=$} & $\begin{array}{l}7 \% \\
0 \%\end{array}$ \\
\hline \multicolumn{2}{|c|}{$\# 29\left(\mathrm{~T}_{2} \mathrm{~N}_{2 \mathrm{~b}} \mathrm{M}_{0}\right), 59, \mathrm{~m}$} & \multirow{2}{*}{\multicolumn{4}{|c|}{$0.7 /$ n.a. $\quad 1006 \%$}} & \\
\hline \multicolumn{2}{|l|}{ Prim. } & & & & & $1 \%$ \\
\hline \multirow{2}{*}{\multicolumn{2}{|c|}{$\begin{array}{l}\text { Meta. } \\
\text { LN }\end{array}$}} & $0.5 / 18 \%$ & $1,0.100 .7 \%$ & $1.8 / 10.8 \%$ & & $8 \%$ \\
\hline & & \multicolumn{4}{|c|}{$1.0770 \%$} & $0 \%$ \\
\hline \multicolumn{7}{|c|}{$\# 47\left(\mathrm{~T}_{4} \mathrm{~N}_{0} \mathrm{M}_{0}\right), 42, \mathrm{~m}$} \\
\hline Prim. & Eos+ & \multirow{2}{*}{\multicolumn{4}{|c|}{ 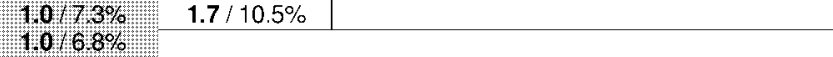 }} & $9 \%$ \\
\hline LN & & & & & & $1 \%$ \\
\hline \multicolumn{7}{|c|}{$\# 56\left(\mathrm{~T}_{3} \mathrm{~N}_{2 \mathrm{~b}} \mathrm{M}_{0}\right), 62, \mathrm{~m}$} \\
\hline \multirow{2}{*}{\multicolumn{2}{|c|}{\begin{tabular}{|l|l|} 
Prim. & Eost \\
\end{tabular}}} & \multirow{3}{*}{$\begin{array}{l}1.0 .13 .6 \% \\
1.2 / 10.9 \% \\
1.0 \% 8.0 \%\end{array}$} & \multirow{3}{*}{\begin{tabular}{|l|l|}
$1.2 / 13.6 \%$ & \\
$2.5 / 9.4 \%$ & \\
\end{tabular}} & \multirow[t]{2}{*}{$2.0 /$ n.a. } & $2.7 /$ n.a. & \multirow{2}{*}{$\begin{array}{l}10 \% \\
12 \% \\
\end{array}$} \\
\hline & & & & & & \\
\hline \multicolumn{2}{|r|}{ Eost } & & & & & $0 \%$ \\
\hline \multicolumn{2}{|c|}{$\# 58\left(\mathrm{~T}_{2} \mathrm{~N}_{2 \mathrm{~b}} \mathrm{M}_{0}\right), 63, \mathrm{~m}$} & & \\
\hline Prim. & Eost & \multirow{2}{*}{$\begin{array}{l}1.0 .123 \% \\
1.2 / 14.2 \%\end{array}$} & $1.9 / 8.7 \%$ & $3.8 / 4.5 \%$ & & $16 \%$ \\
\hline $\begin{array}{l}\text { Meta. \#1 } \\
\text { Meta. \#2 }\end{array}$ & Eost & & $\begin{array}{l}2.4 / 16.3 \% \\
1.7 / 9.0 \%\end{array}$ & \multicolumn{2}{|l|}{$3.7 / 5.8 \%$} & $\begin{array}{l}10 \% \\
11 \%\end{array}$ \\
\hline \multicolumn{7}{|c|}{$\# 75\left(\mathrm{~T}_{2} \mathrm{~N}_{0} \mathrm{M}_{0}\right), 71, \mathrm{f}$} \\
\hline Prim. & & $10.99 \%$ & $1.4 /$ n.a. & & & $10 \%$ \\
\hline LN & & \multicolumn{4}{|l|}{$1.014 .6 \%$} & $1 \%$ \\
\hline$\# 98\left(\mathrm{~T}_{2} \mathrm{~N}_{2 \mathrm{~b}} \mathrm{I}\right.$ & $2, m$ & & & & & \\
\hline Prim. & Eost & $1.0 \%$ / $19 \%$ & $1.5 /$ n.a. & $2.2 /$ n.a. & & $17 \%$ \\
\hline $\begin{array}{l}\text { Meta. } \\
\text { LN }\end{array}$ & & $\begin{array}{l}1.1 / \mathrm{n} \cdot \mathrm{a} \\
1.0 / 8.7 \%\end{array}$ & $2.2 /$ n.a. & & & $\begin{array}{l}6 \% \\
0 \%\end{array}$ \\
\hline$\# 145\left(\mathrm{~T}_{3} \mathrm{~N}_{1} \mathrm{I}\right.$ & $0, m$ & & & & & \\
\hline Prim. & & $0.6 /$ n.a. & $10 / 99 \%$ & $1.6 / 7.5 \%$ & $2.0 /$ n.a. & $15 \%$ \\
\hline Meta. & & $0.5 /$ n.a. & $0.8 / 9.7 \%$ & $10.89 \%$ & $3.3 / 7.3 \%$ & $20 \%$ \\
\hline LN & & $10.44 \%$ & & & & $0 \%$ \\
\hline$\# 147\left(\mathrm{~T}_{4} \mathrm{~N}_{2 \mathrm{c}}\right.$ & $57, m$ & & & & & \\
\hline Prim. & & $0.4 / 25.7 \%$ & $10.9 .8 \%$ & $1.6 / 5.2 \%$ & $3.2 /$ n.a. & $12 \%$ \\
\hline Meta. \#1 & & $1.2 / 9.2 \%$ & & & & $10 \%$ \\
\hline Meta. \#2 & & $10.77 \%$ & $1.5 /$ n.a. & $3.1 /$ n.a. & & $4 \%$ \\
\hline LN & & $10.152 \%$ & & & & $0 \%$ \\
\hline$\# 191\left(\mathrm{~T}_{4} \mathrm{~N}_{2 \mathrm{c}}\right.$ & $56, m$ & & & & & \\
\hline Prim. & & $10175 \%$ & $1.2 / 7.2 \%$ & $1.9 / 6.0 \%$ & $2.4 /$ n.a. & $21 \%$ \\
\hline Meta. \#1 & Eost & $0.7 / 14.8 \%$ & U: $10: 5,5 \%$ & $1.6 / 6.3 \%$ & & $7 \%$ \\
\hline Meta. \#2 & & $10.77 \%$ & $1.8 / 6.4 \%$ & & & $19 \%$ \\
\hline$\# 196\left(\mathrm{~T}_{4} \mathbf{N}_{2} \mathrm{I}\right.$ & $99, \mathrm{~m}$ & & & & & \\
\hline Prim. & & $0.6 / 15.0 \%$ & $10: 170 \%$ & $1.3 / 4.9 \%$ & $2.4 /$ n.a. & $13 \%$ \\
\hline$\overline{782}=$ Aden & 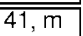 & $1.0766 \%$ & & & & $3 \%$ \\
\hline $\begin{array}{l}\text { Eos+ indica } \\
\text { The other st }\end{array}$ & $\begin{array}{l}\text { רat diplo } \\
\text { eens did }\end{array}$ & $\begin{array}{l}\text { bright green ce } \\
\text { ontain neither e }\end{array}$ & $\begin{array}{l}\text { ells exsisted an } \\
\text { osinophils nor }\end{array}$ & $\begin{array}{l}\text { hat these cells } \\
\text { loid bright gre }\end{array}$ & $\begin{array}{l}\text { re identified as eosinophils. } \\
\text { ells. }\end{array}$ & \\
\hline n.a. $=$ not ap & ble dus & o cell count $<10$ & & & & \\
\hline
\end{tabular}

Specimens from eleven patients with histologically confirmed hypopharyngeal carcinoma and from one patient with pleomorphic adenoma of the parotid gland were analyzed. In the cytokeratin-negative fraction the diploid reference population was defined by re-localization and its DI was set to 1.0. In the DNA-histogram of the cytokeratin-positive fraction the aneuploid peaks were verified to consist of single cells only and their DI was calculated. The $\mathrm{CV}$ of every peak was determined. The 5cER was calculated for the cytokeratin-positive cells. For disease-free lymph nodes and the only non-cytokeratin positive tumor (patient \#58, meta \#2) calculations were performed on all cells. 

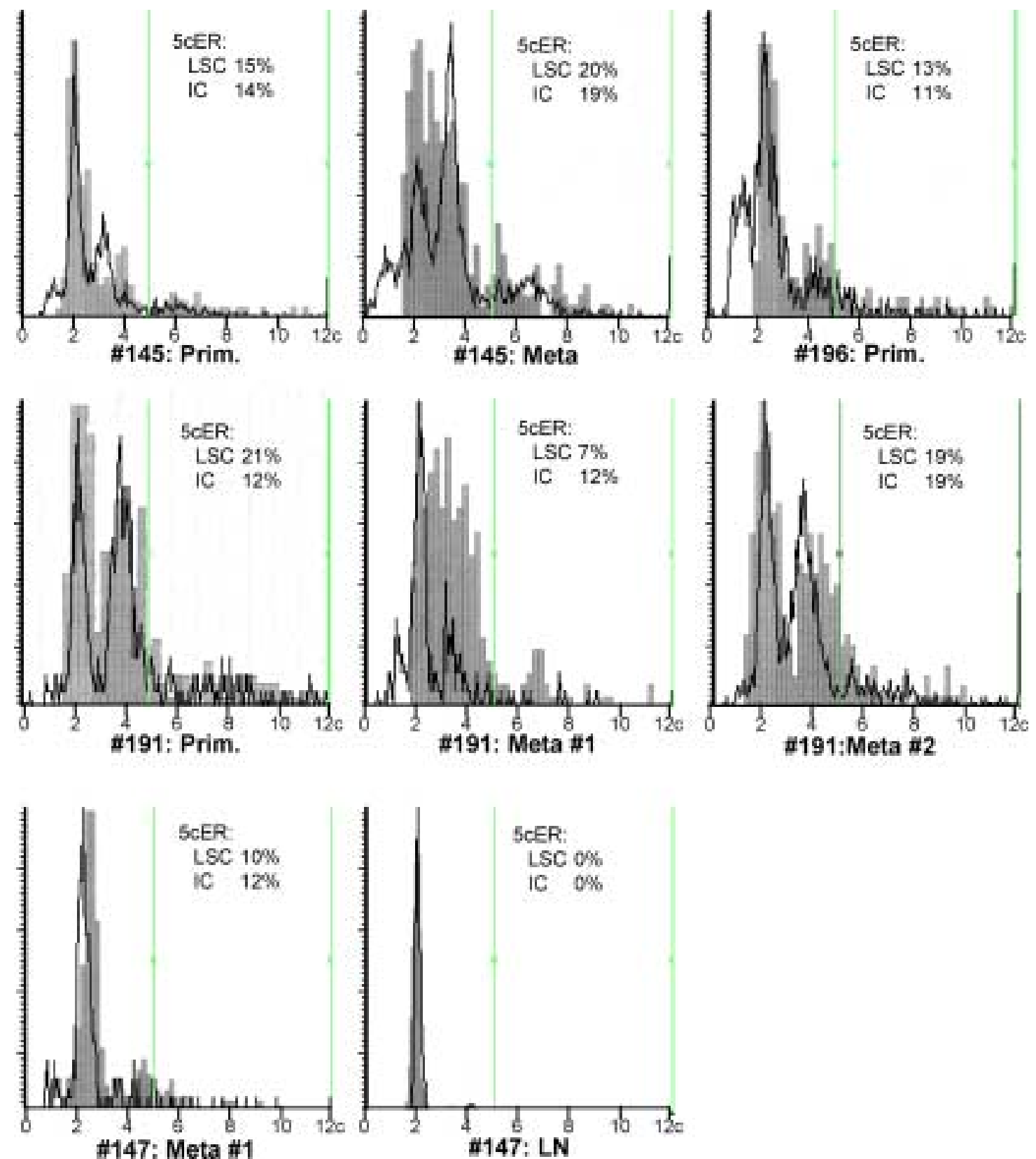

Fig. 4. Overlay of DNA histograms obtained by LSC (straight line) and by image cytometry (solid graph) for eight specimens. $\mathrm{x}$-axis was scaled to $12 \mathrm{c}$ for all cases. This figure can be viewed on http://www.esacp.org/acp/2003/25-2/gerstner.htm 


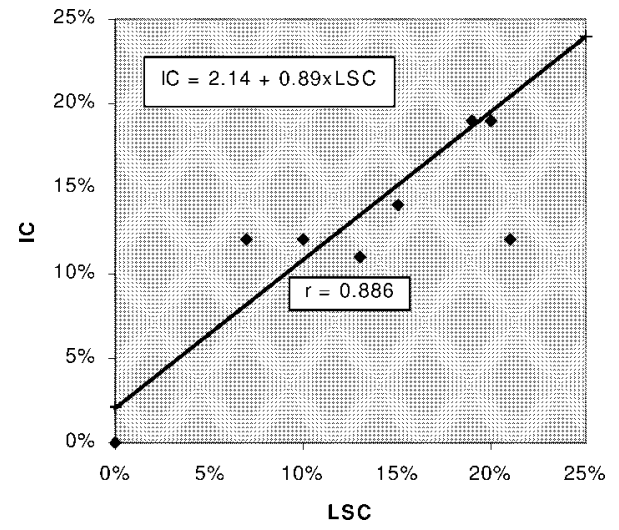

Fig. 5. Correlation of the 5cER determined by LSC (x-axis) vs. the 5 cER determined by IC (y-axis) for eight specimens. Specimens were split into two aliquots and were stained separately with PI + anti-cytokeratin for LSC and with Feulgen-staining for IC, respectively; insert $=$ regression equitation, $r=$ Pearson's coefficient of correlation.

entities [29]. In head and neck cancer, the percentage of the 5cER was shown to be prognostically significant for the overall survival in T1 squamous cell carcinoma of the oral cavity [40]; it has also been shown that the existence of an aneuploid stem line is associated with the development of neck metastases in oroand hypopharyngeal carcinoma [41] and with a marked decrease in the 5-year overall survival $[19,21,22]$. The role of aneuploidy is particularly demonstrated by the observation that patients with aneuploid premalignant lesions (such as leukoplakias and erythroplakias) have a high risk to develop oral cancer exceeding the risk of patients with diploid lesions by far [36,37].

On this background, in the present study we aimed to develop and test an application of slide-based cytometry such as LSC for the determination of the ploidy in SCCH; the LSC is a relatively new instrument that allows to perform multiparametric analyses of minimal sample volumes (for review see [38]). We also wanted to compare the results with standard image cytometry using Feulgen-staining. For image cytometry, we performed a protocol consistent with the recommendations by the ESACP $[14,16,17]$. For LSC, existing protocols for tumor analysis so far used material obtained by imprinting or scratching the surface of the resected specimen $[5,15]$, paraffin-embedded material [23], body fluids, effusions, or washes [42]. However, for solid tumors this material is only available after surgical resection. Our main interest was to develop a method that can be applied preoperatively as part of the routine clinical examination. In tumors that are accessible for direct inspection such as oral can- cer recently cytological scrapings have been used for ploidy analysis by image cytometry [31]. This technology can be adapted for hypopharyngeal and laryngeal cancer, too, in order to obtain cytological samples by an experienced otorhinolaryngologist on an out-patient basis; however, it cannot be applied for the corresponding metastases. We rather concentrated on FNABs because it promised to yield semi-non invasively specimens also from the metastases on an outpatient basis. The biopsies from the primary hypopharyngeal carcinomas were obtained directly after resection of the tumor under general anesthesia. Moreover, FNAB is a well established procedure for diagnosis and treatment follow-up in several tumor entities [6,7, 34]. We developed a modification of the existing techniques: the aspirate is transferred into a solution rather than placed directly onto the slide. Once in solution the specimen can be modified in different ways. For example, this allows to lyse "contaminating" erythrocytes and to remove most of the cell debris by centrifugation. The solution can be further diluted in order to optimize the cellular density on the slide and to avoid densely packed and overlapping cell conglomerates. This might lead to some loss of information by disaggregating cell complexes that could help in establishing the diagnosis solely by conventional cytology. However, after analysis in the LSC cells can easily be assessed on the slide by cytological examination nevertheless.

Since we were working with FNABs we did not compare LSC with flow cytometry due to the minimal sample size but rather choose image cytometry in order to compare results on ploidy and 5cER. We found a good correlation of the two methods using FNABs as has been shown previously by others using single cell or nuclei suspensions from tissue blocks or imprints [5, $28,32,33]$. We conclude from this observation that LSC analysis of FNABs can be applied for the determination of the ploidy of a tumor pre-operatively. In our opinion LSC might have some advantages as compared to image cytometry: (A) with LSC much higher cell counts can easily be achieved than with image cytometry (about 300 cells for routine examinations) [18,31, 39,40 ]; however, this increase in cell count very likely will not result in different ploidy values but rather in the detection of rare cells such as mitotic cells [12]. (B) In image cytometry cells are selected by the observer and therefore a substantial bias on the malignant cell population might result from preferring grossly atypical cells; this needs training in morphological analysis and helps to concentrate on the most interest- 
ing cells (i.e., the malignant cells) but could explain the sub-optimal correlation of the $5 \mathrm{cER}$ determined by image cytometry and LSC in our study. (C) In image cytometry mostly only parameters concerning the cellular DNA (e.g., ploidy) can be analyzed. Since with LSC up to six colors can be measured at once [11] it offers the opportunity to analyze nuclear DNA and additionally other characteristics such as the immunophenotype [4]; other combined applications in future could include FISH and immunohistochemistry (e.g., cyclin $\mathrm{B} 1, \mathrm{Ki} 67)$. The principle of repeatedly staining and reanalyzing the same cells has successfully been applied for immunophenotyping recently [13].

The CV for the peaks in the DNA-histogram obtained by our protocol is higher than that obtained by flow cytometry using DAPI or ethidium bromide [19$21]$ or PI $[9,26]$ for nuclear staining. Compared to LSC these protocols are superior in terms of the $\mathrm{CV}$, but have substantial drawbacks. The material needed for analysis exceeds that for LSC by far making analysis of FNABs hardly possible. In general, with flow cytometry cells cannot be studied a second time by different methods disabling the morphological analysis of the detected "events"; the only exceptions are cell sorters which are technically demanding to operate and time consuming or flow cytometers with real-time videoscopy. These problems are solved by LSC: specimens are analyzed in a "no cell-loss" slide based manner. Its major advantage is the re-localization feature. Without this means it would have been very difficult to interpret the histogram shown in Fig. 3 correctly since the metastasizing cells did not stain with the cytokeratin antibody. Interestingly, as shown in Fig. 4 there were often differences in the ploidy of the primary tumor as compared to the metastatic disease. This could be interpreted as an effect of field cancerization with multi-clonal cancerogenesis; in order to further investigate this issue future studies should include swabs or scrapings also from adjacent and healthy mucosa as well as from distant sites such as bronchi or esophagus.

Analyses by flow cytometry showed diploid cells that appeared to be positively stained for cytokeratin [30]; these cells were considered to play a role in tumor progression. In our specimens we detected a similar population with diploid DI that exhibited bright green fluorescence. However, by re-localization we made the observation that this population consisted of eosinophilic granulocytes but not of epithelial cells. From other observations such as the TUNEL-assay it is well known and documented that eosinophilic granulocytes have very high affinity to unconjugated FITC [1].
It has even been proposed to use eosinophilic granulocytes to clear antibody formulations from unconjugated FITC. Consistent with this interpretation is the fact that we observed these bright green diploid cells also in the negative samples stained with irrelevant FITC-conjugated control antibody and identified them as eosinophils. This problem could be circumvented by using a different fluorochrome to detect anticytokeratin antibody binding, e.g., allophycocyanine.

\section{Conclusion}

Our data show that LSC provides a reliable and objective way to determine the ploidy of solid tumors such as SCCH on an out-patient basis. It needs only minimal sample volumes such as FNABs and its clinical application could further be enlarged by using swabs or scrapings. This combined microanalytical approach might help to establish cytometric analyses as part of the routine diagnostic repertoire pre-operatively and therefore could yield further improvements in the therapy outcome.

\section{References}

[1] E. Bedner, H. Halicka, W. Cheng, T. Salomon, A. Deptala, W. Gorczyca, M. Melamed and Z. Darzynkiewicz, High affinity of fluorescein isothiocyanate to eosinophils detected by laser scanning cytometry: a potential source of error in analysis of blood samples utilizing fluorescein-conjugated reagents in flow cytometry, Cytometry 36 (1999), 77-82.

[2] A. Böcking, DNA-measurements, When and why?, in: Compendium on Quality Assurance, Proficiency Testing, and Workload Limitations in Clinical Cytology, G.L. Wied, P.H. Bartels, D.L. Rosenthal and U. Schenk, eds, Tutorial of Cytology, Chicago, 1995, pp. 170-188.

[3] A. Böcking and H. Motherby, Diagnosis of cervical dysplasia using DNA image cytometry, Pathologe 20 (1999), 25-33.

[4] R.J. Clatch, J.L. Walloch, M.M. Zutter and L.A. Kamentsky, Immunophenotypic analysis of hematologic malignancy by laser scanning cytometry, Am. J. Clin. Pathol. 105 (1996), 744755

[5] R.J. Clatch, J.L. Walloch, J.R. Foreman and L.A. Kamentsky, Multiparameter analysis of DNA content and cytokeratin expression in breast carcinoma by laser scanning cytometry, Arch. Pathol. Lab. Med. 121 (1997), 585-592.

[6] R.J. Clatch and J.L. Walloch, Multiparameter immunophenotypic analysis of fine needle aspiration biopsies and other hematologic specimens by laser scanning cytometry, Acta Cytol. 41 (1997), 109-122.

[7] M. Dowsett, S. Detre, M.G. Ormerod, P.A. Ellis, P.N. Mainwaring, J.C. Titley and I.E. Smith, Analysis and sorting of apoptotic cells from fine-needle aspirates of excised human primary breast carcinomas, Cytometry 32 (1998), 291-300. 
[8] K. Feulgen and H. Rossenbeck, Mikroskopisch-chemischer Nachweis einer Nucleinsäure vom Typus der Thymonucleinsäure und die darauf beruhende elektive Färbung von Zellkernen in mikroskopischen Präparaten, Hoppe Seyler Z. Physiolog. Chem. 135 (1924), 203-248.

[9] G. Franzén, O.G. Klausen, R.T. Grenko, J. Carstensen and B. Nordenskjöld, Adenoid cystic carcinoma: DNA as a prognostic indicator, Laryngoscope 101 (1991), 669-673.

[10] A.O.H. Gerstner, W. Laffers, F. Bootz and A. Tárnok, Immunophenotyping of peripheral blood leukocytes by laser scanning cytometry, J. Immunol. Meth. 246 (2000), 175-185.

[11] A.O.H. Gerstner, D. Lenz, W. Laffers, R.A. Hoffman, M. Steinbrecher, F. Bootz and A. Tárnok, Near-infrared dyes for six color immunophentyping by LSC, Cytometry 48 (2002), 115123.

[12] A.O.H. Gerstner, J. Machlitt, A.-K. Müller, A. Tárnok, J. Oeken and F. Bootz, Multiparametric analysis of fine needle aspirate biopsies from parotid tumors by laser scanning cytometry (LSC), in: Clinical Diagnostic Systems: Technologies and Instrumentation, G.E. Cohn, ed., San José, CA, 2002, SPIE, Vol. 4625, pp. 9-19.

[13] A.O.H. Gerstner, W. Laffers, F. Bootz and A. Tárnok, Novel approaches for immunophenotyping by Laser Scanning Cytometry (LSC), in: Optical Diagnostics of Living Cells V, D.L. Farkas and R.C. Leif, eds, San José, CA, 2002, SPIE, Vol. 4622, pp. 240-249.

[14] F. Giroud, G. Haroske, A. Reith and A. Böcking, 1997 ESACP consensus report on diagnostic DNA image cytometry. Part II: Specific recommendation for quality assurance. European Society for Analytical Cellular Pathology, Anal. Cell. Pathol. 17 (1998), 201-208.

[15] W. Gorczyca, Z. Darzynkiewicz and M.R. Melamed, Laser scanning cytometry in pathology of solid tumors - a review, Acta Cytol. 41 (1997), 98-108.

[16] G. Haroske, F. Giroud, A. Reith and A. Böcking, 1997 ESACP consensus report on diagnostic DNA image cytometry. Part I: Basic considerations and recommendations for preparation, measurement and interpretation, Anal. Cell. Pathol. 17 (1998), 189-200.

[17] G. Haroske, J.P.A. Baak, H. Danielsen, F. Giroud, A. Gschwendtner, M. Oberholzer, A. Reith, P. Spieler and A. Böcking, Fourth updated ESACP consensus report on diagnostic DNA image cytometry, Anal. Cell. Pathol. 23 (2001), 8995 .

[18] S. Hassid, M.P. Degaute, S. Dawance, K. Rombaut, N. Nagy, G. Choufani, C. Decaestecker, A. Danguy, I. Salmon and R. Kiss, Determination of proliferative activity in nasal polyps, J. Clin. Pathol. 50 (1997), 923-928.

[19] J. Hemmer and E. Schön, Cytogenetic progression and prognosis in oral carcinoma: a DNA flow cytometric study in 317 cases, Int. J. Oncol. 3 (1993), 635-640.

[20] J. Hemmer and W. Prinz, Comparison of DNA flow cytometry and fluorescence in situ hybridization with a set of 10 chromosome-specific DNA probes in four head and neck carcinomas, Cancer. Gent. Cytogenet. 97 (1997), 35-38.

[21] J. Hemmer, T. Thein and W.F.P. van Heerden, The value of DNA flow cytometry in predicting the development of lymph node metastasis and survival in patients with locally recurrent oral squamous cell carcinoma, Cancer 79 (1997), 2309-2313.
[22] J. Hemmer, E. Nagel and K. Kraft, DNA aneuploidy by flow cytometry is an independent prognostic factor in squamous cell carcinoma of the oral cavity, Anticancer Res. 19 (1999), 14191422.

[23] T. Kamada, K. Sasaki, T. Tsuji, T. Todoroki, M. Takahashi and A. Kurose, Sample preparation from paraffin-embedded tissue specimens for laser scanning cytometric DNA analysis, Cytometry 27 (1997), 290-294.

[24] L.A. Kamentsky and L.D. Kamentsky, Microscope-based multiparameter laser scanning cytometer yielding data comparable to flow cytometry data, Cytometry 12 (1991), 381-387.

[25] L.A. Kamentsky, D.E. Burger, R.J. Gershman, L.D. Kamentsky and E. Luther, Slide-based laser scanning cytometry, Acta Cytol. 41 (1997), 123-143.

[26] M.P.G. Leers, B. Schutte, P.H.M.H. Theunissen, F.C.S. Ramaekers and M. Nap, Heat pretreatment increases resolution in DNA flow cytometry of paraffin-embedded tumor tissue, $C y$ tometry 35 (1999), 260-266.

[27] R. Li, A. Sonik, R. Stindl, D. Rasnick and P. Duesberg, Aneuploidy vs. gene mutation hypothesis of cancer: recent study claims mutation but is found to support aneuploidy, Proc. Natl. Acad. Sci. USA 28 (2000), 3236-3241.

[28] D.G. Martin-Reay, L.A. Kamentsky, D.S. Weinberg, K.A. Hollister and E.S. Cibas, Evaluation of a new slide-based laser scanning cytometer for DNA analysis of tumors - comparison with flow cytometry and image analysis, Am. J. Clin. Pathol. 102 (1994), 432-438.

[29] C. Millot and J. Dufer, Clinical applications of image cytometry to human tumour analysis, Histol. Histopathol. 15 (2000), 1185-1200.

[30] J. Polackova and J. Hemmer, Progression of diploid tumor cells in aneuploid head and neck squamous cell carcinomas, Int. J. Oncol. 15 (1999), 315-320.

[31] T.W. Remmerbach, H. Weidenbach, N. Pomjanski, K. Knops, S. Mathes, A. Hemprich and A. Böcking, Cytologic and DNAcytometric early diagnosis of oral cancer, Anal. Cell. Pathol. 22 (2001), 211-221.

[32] D.A. Rew, L.J. Reeve and G.D. Wilson, Comparison of flow and laser scanning cytometry for the assay of cell proliferation in human solid tumors, Cytometry 33 (1998), 355-361.

[33] K. Sasaki, A. Kurose, Y. Miura, T. Sato and E. Ikeda, DNA ploidy analysis by laser scanning cytometry (LSC) in colorectal cancers and comparison with flow cytometry, Cytometry $\mathbf{2 3}$ (1996), 106-109.

[34] U. Schröder, H.E. Eckel, V. Rasche, G. Arnold, M. Ortmann and E. Stennert, The value of fine-needle aspiration biopsy in the diagnosis of parotid gland neoplasms, HNO 48 (2000), 421-429.

[35] S. Sen, Aneuploidy and cancer, Curr. Opin. Oncol. 12 (2000), 82-88.

[36] J. Sudbø, W. Kildal, B. Risberg, H.S. Koppang, H.E. Danielsen and A. Reith, DNA content as a prognostic marker in patients with oral leukoplakia, N. Engl. J. Med. 344 (2001), 1270-1278.

[37] J. Sudbø, W. Kildal, A.C. Johannessen, H.S. Koppang, A. Sudbø, H.E. Danielsen, B. Risberg and A. Reith, Gross genomic aberrations in precancers: clinical implications of a long-term follow-up study in oral erythroplakias, J. Clin. Oncol. 20 (2002), 456-462. 
[38] A. Tárnok and A.O.H. Gerstner, Clinical applications of laser scanning cytometry (LSC), Cytometry 50 (2002), 133-143.

[39] N. Wang, C. Wilkin, A. Böcking and B. Tribukait, Evaluation of tumor heterogeneity of prostate carcinoma by flow- and image DNA cytometry and histopathological grading, Anal. Cell. Pathol. 20 (2000), 49-62.

[40] H.J. Welkoborsky, J.L. Gluckman, R. Jacob, H. Bernauer and W.J. Mann, Tumor biologic prognostic parameters in $\mathrm{T}_{1} \mathrm{~N}_{0} \mathrm{M}_{0}$ squamous cell carcinomas of the oral cavity, Laryngo. Rhino. Otol. 78 (1999), 131-138.
[41] H.J. Welkoborsky, H.S. Bernauer, H.S. Riazimand, R. Jacob, W.J. Mann and M.L. Hinni, Patterns of chromosomal aberrations in metastasizing and nonmetastasizing squamous cell carcinomas of the oropharynx and hypopharynx, Ann. Oto. Rhino. Laryngol. 109 (2000), 401-410.

[42] E.M. Wojcik, S.A. Saraga, J.K. Jin and J.B. Hendricks, Application of laser scanning cytometry for evaluation of DNA ploidy in routine cytologic specimens, Diagn. Cytopathol. 24 (2001), 200-205. 


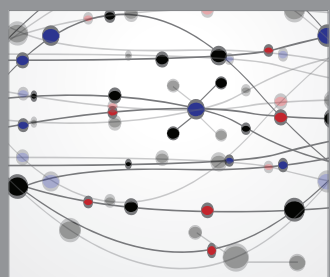

The Scientific World Journal
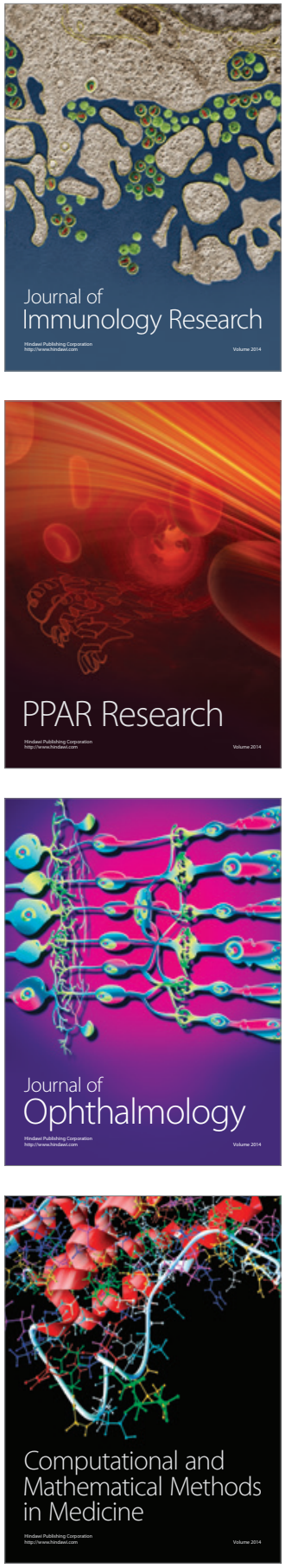

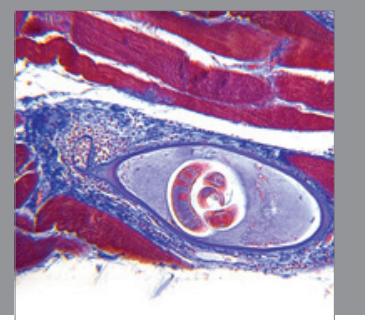

Gastroenterology

Research and Practice
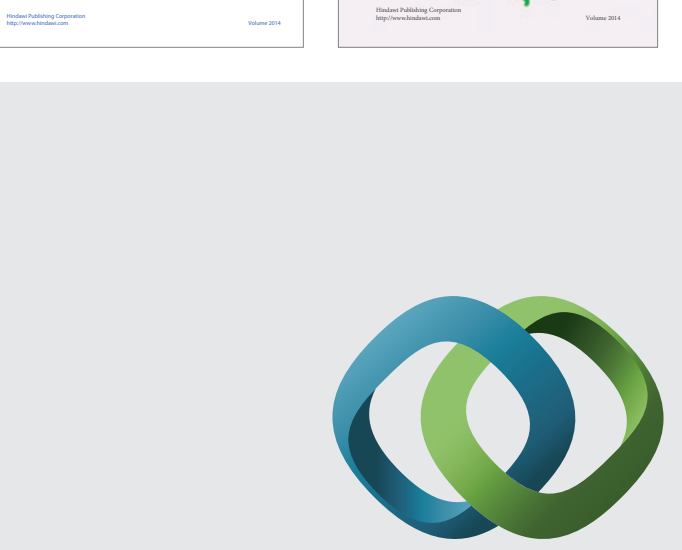

\section{Hindawi}

Submit your manuscripts at

http://www.hindawi.com
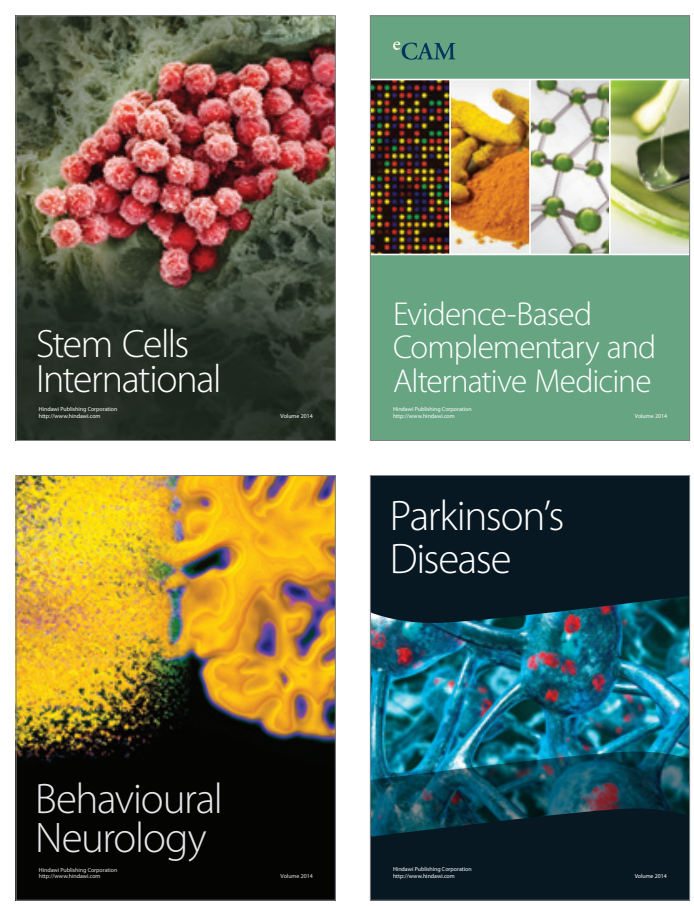

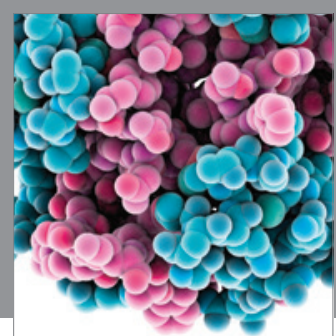

Journal of
Diabetes Research

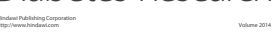

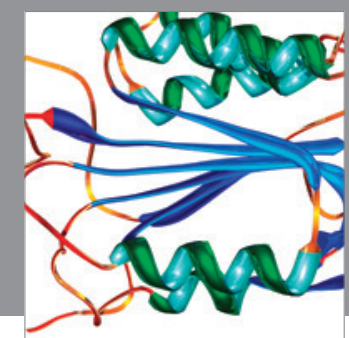

Disease Markers
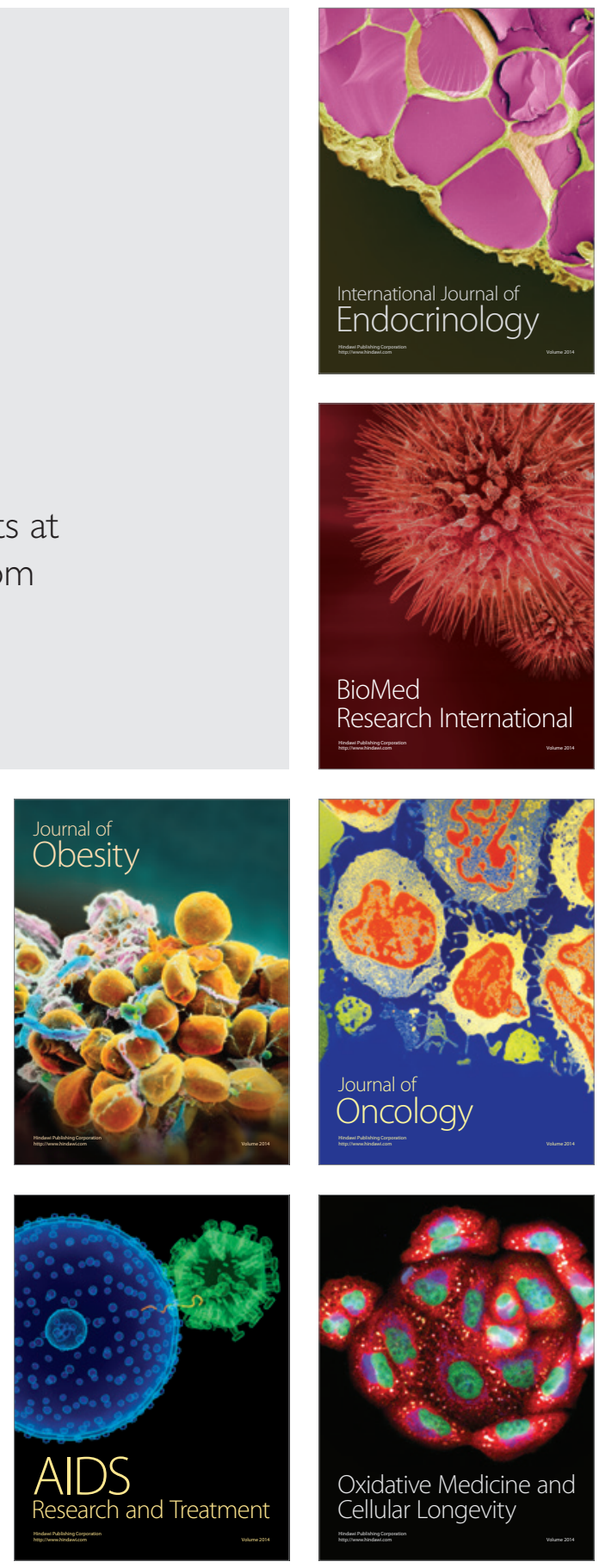